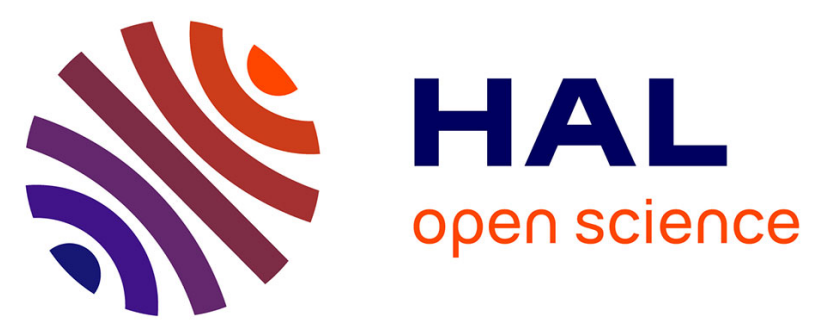

\title{
Genetic isolation between two sympatric host-plant races of the European corn borer, Ostrinia nubilalis Hubner. I. Sex pheromone, moth emergence timing, and parasitism
}

Yan Thomas, Marie-Thérèse Bethenod, Laurent Pélozuelo, Brigitte Frérot, Denis D. Bourguet

\section{To cite this version:}

Yan Thomas, Marie-Thérèse Bethenod, Laurent Pélozuelo, Brigitte Frérot, Denis D. Bourguet. Genetic isolation between two sympatric host-plant races of the European corn borer, Ostrinia nubilalis Hubner. I. Sex pheromone, moth emergence timing, and parasitism. Evolution - International Journal of Organic Evolution, 2003, 57 (2), pp.261-273. 10.1111/j.0014-3820.2003.tb00261.x . hal-02671702

\section{HAL Id: hal-02671702 \\ https://hal.inrae.fr/hal-02671702}

Submitted on 2 Sep 2020

HAL is a multi-disciplinary open access archive for the deposit and dissemination of scientific research documents, whether they are published or not. The documents may come from teaching and research institutions in France or abroad, or from public or private research centers.
L'archive ouverte pluridisciplinaire HAL, est destinée au dépôt et à la diffusion de documents scientifiques de niveau recherche, publiés ou non, émanant des établissements d'enseignement et de recherche français ou étrangers, des laboratoires publics ou privés. 


\title{
GENETIC ISOLATION BETWEEN TWO SYMPATRIC HOST-PLANT RACES OF THE EUROPEAN CORN BORER, OSTRINIA NUBILALIS HÜBNER. I. SEX PHEROMONE, MOTH EMERGENCE TIMING, AND PARASITISM
}

\author{
Yan Thomas, ${ }^{1}$ Marie-Thérèse Bethenod, ${ }^{1}$ Laurent Pelozuelo, ${ }^{2}$ Brigitte Frérot, ${ }^{2}$ And \\ Denis Bourguet ${ }^{1,3}$ \\ ${ }^{1}$ Unité de Recherches de Lutte biologique, Institut National de la Recherche Agronomique La Minière, \\ 78285 Guyancourt Cedex, France \\ ${ }^{2}$ Unité de Phytopharmacie et des Médiateurs chimiques, Institut National de la Recherche Agronomique Versailles, \\ Route de Saint-Cyr, 78026 Versailles Cedex, France \\ ${ }^{3}$ E-mail: bourguet@jouy.inra.fr
}

\begin{abstract}
Adaptation to different environments may be a powerful source of genetic differentiation between populations. The biological traits selected in each environment can pleiotropically induce assortative mating between individuals of these genetically differentiated populations. This situation may facilitate sympatric speciation. Successful host shifts in phytophagous insects provide some of the best evidence for the ecological speciation that occurs, or has occurred, in sympatry. The European corn borer, Ostrinia nubilalis (Lepidoptera: Crambidae), colonized maize after its introduction into Europe by humans about 500 years ago. In northern France, two sympatric host races feed on maize (Zea mays) and mugwort (Artemisia vulgaris), respectively. We investigated the factors involved in the genetic isolation of these two races at a field site near Paris, France. We identified two biological differences that might make a significant contribution to the genetic divergence between sympatric populations feeding on the two host plants. First, assortative mating may be due to differences in the moth emergence pattern between the two races: mugwort-race moths emerged on average 10 days earlier than maize-race moths. In addition, the males emerged earlier than females in both races. Hence, the likelihood of mating between maize-race males and mugwort-race females was higher than that of mating between mugwort-race males and maize-race females. Second, the females feeding on mugwort and maize produced sex pheromones with different E/Z isomeric ratios of $\Delta$-11-tetradecenyl acetate. This difference in mate recognition systems reinforces the potential for assortative mating in the two races. During the experiment, overwintering mortality was much lower on maize than on mugwort. This difference was due to a braconid parasitoid wasp, Macrocentrus cingulum, that killed more than 50\% of the larvae overwintering on mugwort but did not infest larvae diapausing on maize. Hence, by colonizing maize, European corn borer populations probably escaped from numerous predators, competitors, and parasitoids, such as M. cingulum. This decrease in host-associated selection may have favored the colonization of this new host. Finally, throughout this experiment we observed selection at two allozyme loci (or at linked loci): Tpi and Mpi. The Tpi locus is tightly linked with the genes involved in the response of the male to the sex pheromone and in developmental timing. The location of these traits on the $\mathrm{Z}$ chromosome may play a role in shortening the time required for the evolution of premating barriers.
\end{abstract}

Key words.-Assortative mating, ecological speciation, host races, host shift, Macrocentrus cingulum, sex linkage, sympatric speciation.

Received May 30, 2002. Accepted October 8, 2002.

Reproductive isolation following geographic isolation (allopatry), which was first proposed by Mayr and Dobzhansky in the 1930s and 1940s, has been the predominant concept in speciation for the last six decades (Via 2001). Sympatric speciation was considered implausible because the conditions required were thought by many to be very unlikely to occur in nature, notably due to the selection/recombination antagonism identified by Felsenstein (1981). This antagonism prevents the formation of linkage disequilibrium between the genes affecting viability and those affecting assortative mating, making the conditions required for sympatric speciation extremely difficult to achieve. The plausibility of sympatric speciation has been progressively reconsidered (Via 2001; Berlocher and Feder 2002). As suggested by Bush (1975), habitat- or host-plant-based assortative mating may enhance host-associated reproductive isolation, therefore alleviating many of the problems of the selection/recombination antagonism. Rice's theoretical work $(1984,1987)$ further showed that this antagonism can be completely eliminated when the same biological traits under divergent ecological selection pleiotropically cause reproductive isolation. Finally, the models developed by Kondrashov and Kondrashov (1999) and by Dieckmann and Doebeli (1999) showed that this kind of speciation is possible even without isolation during the mating period.

In the last decade, an increasing number of empirical examples have provided support to the idea of sympatric speciation: cichlid fish (Wilson et al. 2000); the apple maggot fly, Rhagoletis pomonella (McPheron et al. 1988; Feder et al. 1994, 1998; Feder and Filchak 1999); the yucca moth, Prodexus quiquepunctellus (Groman and Pellmyr 2000); and the Anolis lizards (Losos et al. 1997, 1998, 2000) all provide evidence of speciation that is occurring, or has occurred, in sympatry. A second interesting feature of these examples is that the accumulation of differences causing reproductive isolation between sympatric populations has often been driven by ecological factors (Orr and Smith 1998), a process referred to as ecological speciation (Schluter 1998, 2001). Ecological speciation occurs in many sympatric races of herbivores feeding on different hosts. This is the case with the pea aphid, Acyrthosiphon pisum (Via 1999; Via et al. 2000); the goldenrod ball-gall fly, Eurosta solidaginis (Abrahamson et al. 2001; Craig et al. 2001); the treehopper, Enchenopa binotata complex (Wood and Keese 1990; Wood et al. 1999); the larch 
budmoth, Zeiraphera diniana (Emelianov et al. 1995, 2001); and the soapberry bug, Jadera haematoloma (Carroll et al. 2001). In these phytophagous herbivorous species, premating isolation between host-plant races is a by-product of the disruptive selection induced by host plants. This pleiotropy between host adaptation and mate choice reduces the selection/ recombination antagonism and therefore increases the possibility of sympatric speciation. Identification of additional forms of host-related selection that pleiotropically induce assortative mating will improve our understanding of ecological and sympatric speciation.

In this study, we investigated the genetic isolation between two sympatric host plant races of the European corn borer (ECB), Ostrinia nubilalis (Lepidoptera: Crambidae). This polyphagous moth is native to northern Africa, western Asia, and Europe (Hudon et al. 1989) and was accidentally introduced into North America at the beginning of the twentieth century (Baker et al. 1949). More than 20 plants are known to be able to sustain the development of $O$. nubilalis (Hodgson 1928). In Europe, its main hosts are maize (Zea mays) and mugwort (Artemisia vulgaris; Thompson and Parker 1928). The larvae overwinter in the stalks of the host at the fifth instar, then the diapause is broken, the pupation occurs, and the adults emerge at the beginning of summer. Before pupation of the ECB, the main parasitoids of this species-the tachinids Lydella thompsoni and Pseudoperichaeta nigrolineata and the braconid wasp Macrocentrus cingulumemerge from ECB larvae. In northern France, ECB populations that feed on maize are genetically differentiated from those that feed on mugwort (Bourguet et al. 2000; Martel et al. 2003). The definitive taxonomic status of these two genetic entities has not yet been determined. In this article, we use the term "race" to denote a population feeding either on maize or on mugwort. The genetic differentiation between the maize and mugwort races, as assessed on the basis of allozyme and mitochondrial markers, is low (Martel et al. 2003). This low level of differentiation probably results from the two races not having been isolated for long enough to generate substantial genetic divergence (Martel et al. 2003). Indeed, the level of gene flow between populations feeding on the two host plants seems to be very low, as suggested by the genetic isolation by geographical distance patterns within and between the two races. In this paper, we report a first investigation of the biological traits that might contribute to the genetic isolation of these host plant races.

In ECB populations, two genetically controlled traits are involved in reproductive isolation. One of these traits is the sexual pheromone communication system. In America and Europe, $\mathrm{E}$ and $\mathrm{Z}$ populations have already been identified, with females producing differing $\mathrm{E} / \mathrm{Z}$ isomeric ratios of $\Delta$ 11 -tetradecenyl acetate $(\Delta 11-14: \mathrm{OAc})$ and with males responding to the sex pheromone produced by the females of their race. In $\mathrm{Z}$ populations, females produce and males respond to E11-14:OAc /Z11-14:OAc in a ratio of 3:97 ( $\mathrm{Z}$ blend), whereas the opposite blend-99:1 to $97: 3 \mathrm{E} / \mathrm{Z}$ ratio (E blend) - is used in E populations (Klun et al. 1975; Harrison and Vawter 1977; Cardé et al. 1978). Laboratory and field hybridizations between the two populations have been demonstrated, with hybrid females producing pheromone blends with an E/Z ratio of approximately 35:65 (hybrid blend; Klun and Maini 1979; Glover et al. 1991).

The second polymorphic trait involved in reproductive isolation is the number of generations per year (Stengel and Schubert 1982; Glover et al. 1992). Populations of ECB are classified into genetically univoltine (U) population with a compulsory diapause and genetically bivoltine (B) populations with a facultative diapause. Bivoltine populations located in northern Europe and northern North America only achieve one generation per year, whereas in the most southern areas, these populations display up to three or four generations per year (Stengel and Schubert 1982; Glover et al. 1992). In America, U and B populations exist in sympatry in New York State (Glover et al. 1990). In this region, the single peak of emergence of the $U$ populations occurs between the two peaks of emergence of the $\mathrm{B}$ populations, reducing the possibility of interbreeding (Klun and Huettel 1988).

Although the genetic variations and the relationships between voltinism and pheromone composition have been investigated in detail (e.g. Roelofs et al. 1985; Glover et al. 1990) they have never been studied in the context of ecological specialization. Indeed, these two traits have been studied almost exclusively on populations feeding on maize. However, these populations are a recent event caused by a host shift that occurred after the introduction of this crop into Europe (about 500 years ago). Hence, the finding that in northern France ECB populations feeding on maize and mugwort are genetically differentiated opens a new line of research centered on the ecological causes of the speciation of this moth. An obvious question is whether the variations in pheromone composition and voltinism are connected to the genetic divergence of sympatric host-plant populations. We investigated this question by use of a multidisciplinary approach.

The experiment described here took place at a single site located in northern France. European corn borer populations of the maize and mugwort races are intermingled at the site. Our aim was to investigate whether differences in the pattern of moth emergence and in the sex pheromone communication system are involved in the reproductive isolation of the two host plant races. We also investigated host quality for the development of ECB larvae by recording overwintering mortality, parasite load, and moth weight at emergence. Finally, we investigated whether overwintering mortality and moth emergence were accompanied by changes in genetic structure at five allozyme loci.

\section{Materials And Methods \\ Study Site and Sampling}

All ECB were sampled at a single site located in the vicinity of the Institut National de la Recherche Agronomique station at Grignon (Ile-de-France region, France). This site was chosen because maize and mugwort were present at sufficient density and were both substantially infested-approximately 0.6 larvae per stalk-by $O$. nubilalis. For each host plant, approximately 1600 stalks were collected on 17 November 2000. These stalks were randomly assigned to four sets. Set 1 (130 stalks) was used to determine the genetic 
structure of overwintering larvae. These stalks were directly screened for the presence of ECB larvae and a total of 90 and 81 larvae were extracted from maize and mugwort, respectively. These overwintering larvae were sexed and directly frozen at $-80^{\circ} \mathrm{C}$ before electrophoretic analyses. From set 2 (370 stalks) we extracted 183 and 198 larvae overwintering on maize and mugwort, respectively. These larvae were maintained at $4^{\circ} \mathrm{C}$ for diapause completion in laboratory conditions. The stalks of set 3 (about 1,000 stalks) were kept in the field, under two different cages, one for each type of host, covered by nets. The larvae of set 3 were allowed to complete diapause under natural conditions. Finally, set 4 (100 stalks) was used for pheromone analysis. Larvae were extracted from maize and mugwort stalks and kept at $4{ }^{\circ} \mathrm{C}$ for diapause completion.

\section{Post-Diapause Development Time and Moth Emergence}

The time to pupation and the pattern of moth emergence of the two host races were monitored after exposing overwintering larvae to identical and controlled laboratory conditions. The timing of moth emergence was also recorded under field conditions.

Laboratory conditions. - The overwintering larvae extracted from set 2 stalks were kept at $4{ }^{\circ} \mathrm{C}$ for 99 days to allow diapause to be completed. Dead larvae were counted and discarded. Groups of three larvae were placed in plastic cups with a moistened piece of cotton and maintained at $25^{\circ} \mathrm{C}$ under a 16:8 h light : dark (L:D) photoperiod. The larvae were checked every 72 hours for individuals that had undergone pupation, and we kept a record of pupation date and of the sex and the weight of each pupa. Pupae were placed individually in plastic cups and kept in the same laboratory conditions until moth emergence. The date of emergence was recorded and the moth was directly frozen at $-80^{\circ} \mathrm{C}$ for electrophoretic analysis. The time to pupation under diapausebreaking temperature and photoperiod is referred to as postdiapause development (PDD) time (Glover et al. 1992). The larvae were subjected to diapause-breaking environmental conditions on 27 February. Post-diapause development time was calculated as the number of days from this date until pupation and time to emergence was calculated as the number of days from 27 February to emergence.

Field conditions.-From 3 June 2001, the cages containing the stalks of set 3 were monitored for moth emergence. Emerged adults were counted daily, weighed, sexed, and directly frozen at $-80^{\circ} \mathrm{C}$ for electrophoretic analysis.

Data analysis. - We compared means to test for differences in PDD time, time to emergence, and pupa and adult weights between the two host races. We first investigated whether these variables were normally distributed using the ShapiroWilks test, and whether they displayed equal variances using a Bartlett test (Sokal and Rohlf 1981). If variables were not normally distributed, means were compared using Wilcoxon's nonparametric test. For those that were normally distributed, the test used for comparing the means depended on whether the variances were equal. If the distributions displayed unequal variances, we used a Welch analysis of variance, whereas a $t$-test was used if the variances were not statistically different (Sokal and Rohlf 1981). All tests were carried out with JMP IN 3.2.1 software (SAS Institute 1996, Wadsworth Publishing Co., Belmont, CA).

\section{Pheromone Analyses}

The females that emerged from the stalks of set 4 were individually placed in plastic containers with a water supply and were kept in a rearing room under $24 \pm 2^{\circ} \mathrm{C}, 70 \pm 20 \%$ relative humidity, with a 16:8 h (L:D) reversed photoperiod. Sex pheromone was collected individually from two- to fiveday-old females sampled during the calling period (the last three hours of darkness). The pheromone gland was extruded by gentle pressure on the abdomen and kept in this position with metallic forceps.

Pheromone collection.-Pheromones were collected by SPME, as described by Frérot et al. (1997). A Supelco (Bellafonte, PA) SPME fiber (65- $\mu \mathrm{m}$ Carbowax-divinylbenzene) previously cleaned by thermal desorption ( $5 \mathrm{~min}$ in the gas chromatograph-injector hold at $240^{\circ} \mathrm{C}$ ) was gently rubbed on the pheromone gland for $4 \mathrm{~min}$ at room temperature, avoiding scales and anal droplets. Each fiber was then either used directly or wrapped in aluminum foil and stored at $-20^{\circ} \mathrm{C}$ before analysis.

Pheromone identification.-The chemical components of the sex pheromone were identified on a Varian (Les Ulis, France) 3400 gas chromatograph (GC) linked to a Saturn 2 mass spectrograph (electron impact mode, $70 \mathrm{eV}, 40-300$ amu). The GC was equipped with a split-splitless injector and a MDN5 S column (Supelco; $30 \mathrm{~m}, 0.32-\mathrm{mm}$ ID, 0.5$\mu \mathrm{m} \mathrm{df})$. The components adsorbed on the fiber were subjected to thermal desorption in the injector at $250^{\circ} \mathrm{C}$ for $2 \mathrm{~min}$. The column temperature was programmed to increase from $50^{\circ} \mathrm{C}$ to $300^{\circ} \mathrm{C}$, at a rate of $8^{\circ} \mathrm{C} \mathrm{min}-1$ and helium was the carrier gas, at a pressure of 11 psi. Z11-14:OAc and E11-14:OAc were identified by comparing the retention times and masses of natural compounds with those of synthetic samples.

\section{Enzyme Electrophoresis}

Electrophoresis._Allozyme electrophoresis was performed with overwintering larvae extracted from set 1 stalks and adults that emerged from the stalks of sets 2 and 3. For each individual, the head was removed for further analysis and the rest of the body was homogenized in $150 \mu \mathrm{L}$ of tris-EDTA ( $\mathrm{pH} \mathrm{6.8).}$ The homogenates were subjected to horizontal starch gel electrophoresis in tris-borate-EDTA ( $\mathrm{pH}$ 8.6) buffer systems (Pasteur et al. 1987). Six enzymes were resolved, using the methods described by Bourguet et al. (2000): phosphoglucomutase (PGM, EC 8.4.2.2), mannose-6-phosphate isomerase (MPI, EC 5.3.1.8), hydroxybutyrate dehydrogenase (HBDH, EC 1.1.1.30), glucose-phosphate isomerase (GPI, EC 5.3.1.9), aspartate aminotransferase (AAT, EC 2.6.1.1) and triose phosphate isomerase (TPI, EC 5.3.1.1). Tpi is on the $\mathrm{Z}$ chromosome (Glover et al. 1990), the female being heterogametic ( $\mathrm{ZW})$, and the male homogametic (ZZ). Thus, at this locus, males are diploid and females are hemiploid.

Data analysis. - The genetic differentiation between the ECB collected on the two host plants was evaluated by calculating $\hat{\theta}$, an estimator of $F_{\mathrm{ST}}$, as described by Weir and Cockerham (1984), and by testing for allelic differentiation using Fisher's exact tests implemented by GENEPOP 3.3 
TABLE 1. Genetic differentiation between the maize- and the mugwort-feeding populations of Ostrinia nubilalis. Differentiation was measured on overwintering larvae and adults that emerged either in the laboratory or in field conditions. Differentiation is measured by $\hat{\theta}$. $P$ corresponds to the probability value for the exact test of allelic differentiation for each locus and across all loci.

\begin{tabular}{|c|c|c|c|c|c|c|}
\hline & \multicolumn{5}{|c|}{ Locus } & \multirow[b]{2}{*}{ All } \\
\hline & $T p i$ & $G p i$ & Aat & $M p i$ & $P g m$ & \\
\hline \multicolumn{7}{|l|}{ Larvae } \\
\hline$\hat{\theta}$ & 0.011 & 0.027 & -0.001 & 0.187 & 0.035 & 0.071 \\
\hline$P$ & $<10^{-4}$ & $<10^{-4}$ & 0.302 & $<10^{-5}$ & $<10^{-5}$ & $<10^{-5}$ \\
\hline \multicolumn{7}{|l|}{ Adults (lab) } \\
\hline$\hat{\theta}$ & 0.135 & 0.039 & 0.021 & 0.083 & 0.020 & 0.059 \\
\hline$P$ & $<10^{-5}$ & $<10^{-4}$ & 0.017 & $<10^{-4}$ & $<10^{-3}$ & $<10^{-5}$ \\
\hline \multicolumn{7}{|l|}{ Adults (field) } \\
\hline$\hat{\theta}$ & 0.063 & 0.057 & 0.013 & 0.177 & 0.113 & 0.098 \\
\hline$P$ & $<10^{-5}$ & $<10^{-5}$ & 0.212 & $<10^{-5}$ & $<10^{-5}$ & $<10^{-5}$ \\
\hline
\end{tabular}

software (Raymond and Rousset 1995). This analysis was performed on larvae (set 1 stalks) and on both sets of adults (sets 2 and 3 ).

Overwintering mortality and moth emergence may be accompanied by changes in allelic and genotypic frequencies at the five allozyme loci investigated in this study. This may happen either because these loci are directly under selection or because they are in genetic disequilibrium with nonneutral loci. In each host race, we investigated whether there was a selection effect by testing for (1) deviation from Hardy-Weinberg expectations in the three sets of individuals, (2) changes in allelic distribution between overwintering larvae (set 1) and both sets of adults (sets 2 and 3), and (3) variations in allelic frequencies during moth emergence in laboratory (set 2 ) and field (set 3 ) conditions. For each set, the estimator $\hat{f}$ of $F_{\text {IS }}$ (Weir and Cockerham 1984) was calculated at each locus and across all loci, using FSTAT 2.8 (Goudet 1995). Deviation from Hardy-Weinberg expectations was tested with GENEPOP 3.3 (Raymond and Rousset 1995). Differences in allele frequency distributions between the three sets of individuals and variations in allelic frequencies over emergence time were investigated by carrying out Fisher's exact tests, using GENEPOP 3.3 software (Raymond and Rousset 1995). Since Tpi is on the $\mathrm{Z}$ chromosome, the genotypic analysis as well as the $\hat{f}$ calculations were carried out using the males only, whereas the allelic analysis and all the other analysis were carried out on all the individuals.

\section{RESULTS}

\section{Genetic Differentiation between Maize and Mugwort Races}

We first checked that the genetic differentiation between the populations collected on the two host plants previously described by Bourguet et al. (2000) and Martel et al. (2003) was also observed at our sampling site. For all the samples collected, we detected three alleles for Tpi, three for $G p i$, four for Aat, six for Mpi, and five for Pgm. The Hbdh locus showed no polymorphism and was therefore excluded from the analysis. The genetic differentiation between the two host-plant populations, assessed for the larvae (set $1, \hat{\theta}=0.071$ ) and for adults that emerged in laboratory ( set $2, \hat{\theta}=0.059)$ and field (set $3, \hat{\theta}=0.098$ ) conditions was highly significant $(P$
$<0.0001$, Table 1). The $\hat{\theta}$ value differed between loci, with differentiation greatest at the Mpi locus in set $1(\hat{\theta}=0.187)$ and set $3(\hat{\theta}=0.177)$ and at the Tpi locus in set $2(\hat{\theta}=$ $0.135)$. These results confirmed that the populations feeding on the two host plants belonged to two different races.

\section{Post Diapause Development Time and Moth Emergence}

Laboratory conditions. - In laboratory conditions, the ECB extracted from the second set of stalks pupated and emerged a mean of two days earlier in the mugwort race than in the maize race (Fig. 1 and Table 2). This difference was marginally significant for PDD time (Wilcoxon test, $P=0.056$ ) and was just significant for time to emergence (Wilcoxon test, $P=0.044)$. However a male collected on mugwort pupated 15 days later and emerged 17 days later than the other moths (Fig. 1A and 1B). If this outlier was excluded from the analysis, both mean PDD time and mean time to emergence were three days longer for the maize race than for the mugwort race and this difference became highly significant (Wilcoxon test, $P<0.001$ ). Although males pupated earlier than females within the maize race, there was no difference in time to emergence between sexes, in either race (Table 2).

Field conditions. - In natural conditions, the patterns of emergence of the moths of the two host races differed. Emergence from maize stalks followed a bell-shaped curve, whereas emergence from mugwort stalks displayed no specific pattern (Fig. 2). Emergence periods clearly differed between the two host-plant races: almost $60 \%$ of moths emerged from mugwort before 18 June, by which date only $7 \%$ of moths had emerged from maize. The emergence of the two races was separated by a mean of 10 days, this difference being highly significant (Wilcoxon test, $P<0.0001$ ). In the maize race, males emerged a mean of four days earlier than females, this difference being highly significant (Wilcoxon test, $P<$ 0.0001). A similar difference was observed in the mugwort race but, due to the smaller number of moths available for this race, this difference was not significant (Wilcoxon test, $P=0.389$ ).

\section{Pheromone Analyses}

The pheromone glands of the females that emerged from set 4 stalks were analyzed to study the pheromone compositions of the two host-plant races. As previously reported in

TABle 2. Time to pupation (PDD time) and time to emergence in laboratory conditions. In a given column, results with the same letter are not significantly different $(P>0.05) . N$, number of individuals.

\begin{tabular}{lccccc}
\hline \hline & \multicolumn{2}{c}{$\begin{array}{c}\text { Time to pupation } \\
\text { (days) }\end{array}$} & & \multicolumn{2}{c}{$\begin{array}{c}\text { Time to emergence } \\
\text { (days) }\end{array}$} \\
\cline { 2 - 3 } \cline { 5 - 5 } Host-plant race & $N$ & Mean $\pm \mathrm{SE}$ & & $N \quad$ & Mean $\pm \mathrm{SE}$ \\
\hline Mugwort & & & & \\
$\quad$ Males & 16 & $18.8 \pm 8.7^{\mathrm{a}}$ & & 16 & $28.4 \pm 9.1^{\mathrm{a}}$ \\
$\quad$ Females & 30 & $18.8 \pm 5.5^{\mathrm{a}}$ & & 30 & $27.9 \pm 5.2^{\mathrm{a}}$ \\
$\quad$ Both sexes & 46 & $18.8 \pm 6.7$ & & 46 & $28.2 \pm 6.7$ \\
Maize & & & & \\
$\quad$ Males & 63 & $19.7 \pm 4.3^{\mathrm{a}}$ & 58 & $29.5 \pm 4.6^{\mathrm{a}, \mathrm{b}}$ \\
Females & 83 & $21.7 \pm 4.7^{\mathrm{b}}$ & 80 & $30.8 \pm 4.5^{\mathrm{b}}$ \\
Both sexes & 146 & $20.7 \pm 4.6$ & 138 & $30.2 \pm 4.6$ \\
\hline
\end{tabular}


all studies on ECB pheromone (e.g. Klun et al. 1973; Klun and Maini 1979), the studied components of the sex pheromones were the $\mathrm{E}$ and $\mathrm{Z}$ isomers of $\Delta-11-14$ :OAc. The experimental GC procedure produced a clear separation of these two isomers and mass spectra confirmed their identification $\left(\mathrm{m} / \mathrm{z}=43,82,124,138,152,166 ; \mathrm{M}^{+}-60=194, \mathrm{M}^{+}=\right.$ 254) and their purity.

Maize race.-Seven of the 32 female glands analyzed were not considered for identification, due to the absence of pheromone compounds. The 25 remaining glands produced enough pheromone (mean $\pm \mathrm{SD}=19 \pm 14 \mathrm{ng}$ ) to obtain interpretable GC-MS spectra. Data from these spectra indicated that Z11-14:OAc was the main component of the sex pheromone. In nine glands, we detected 0.7 to $2.0 \%$ E11-14: OAc, and in a single female this percentage was as high as 12.9\%. According to Klun and Maini (1979), Z, hybrid, and
E females produce Z11-14:OAc and E11-14:OAc in ratios of $97: 3,35: 65$, and 1:99, respectively. Consequently, the 25 maize-race females analyzed were therefore clearly $\mathrm{Z}$ females. To determine the upper limit of the frequency of non$\mathrm{Z}$ females in this population of the maize race, we assume that our sampling among the population follows a binomial law of probability. The absence of $\mathrm{E}$ and hybrid females among the 25 females identified indicates that the combined frequency of these two phenotypes within this population was less than $11 \%$, using a threshold level of $5 \%$.

Mugwort race.-Thirty-two of the 39 mugwort females analyzed contained sufficient pheromone (mean $\pm \mathrm{SD}=13$ $\pm 13 \mathrm{ng}$ ) to clearly identify E11-14:OAc as the main component. However, in contrast to what has previously been reported for E populations (e.g. Kochansky et al. 1975), no traces of Z11-14:OAc isomer were detected, except for a

A<smiles>CCCCC</smiles>

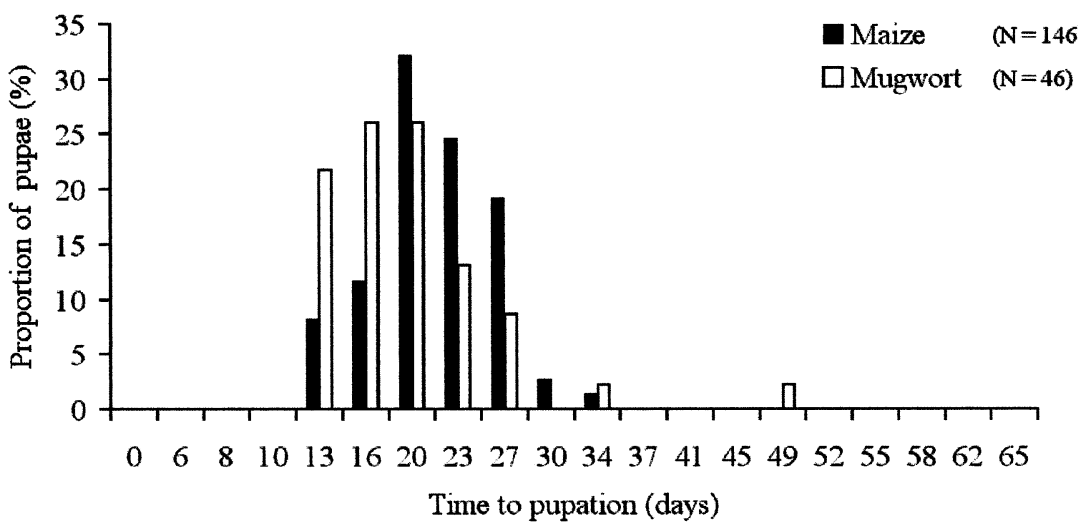

B

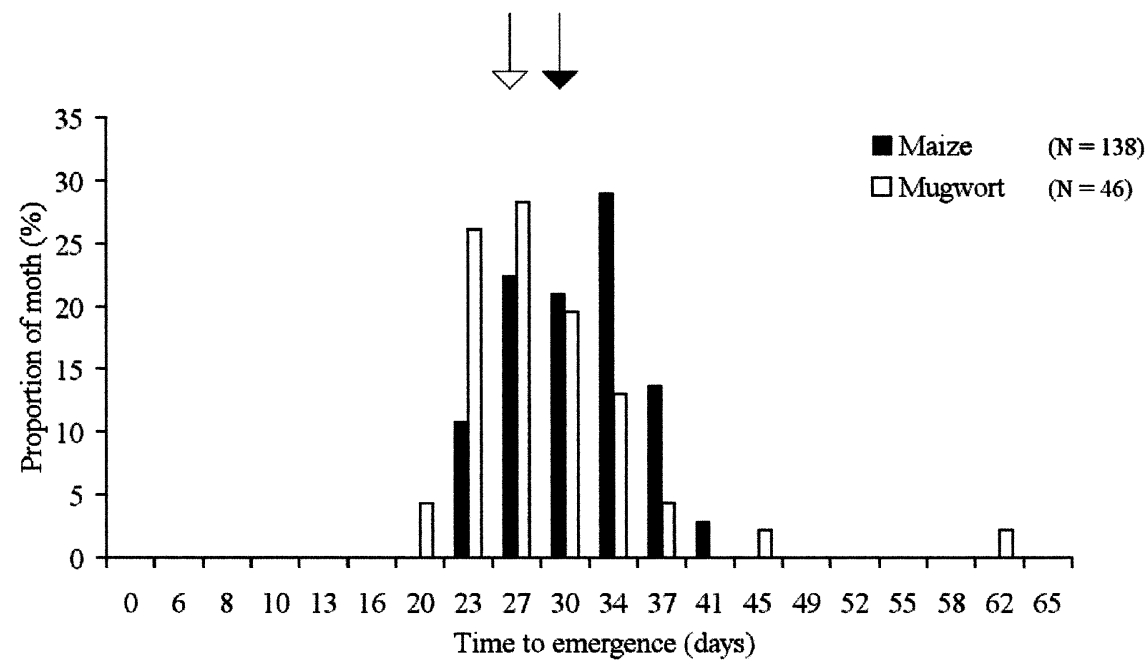

FIG. 1. Proportion of pupae (A) and moths (B) obtained from overwintering larvae kept in controlled laboratory conditions. Filled and open arrows indicate the mean day of pupation and emergence for the maize and mugwort races, respectively. 
TABLE 3. Weight of pupae obtained in laboratory conditions and of adults that emerged in natural conditions. In a given column, results with the same letter are not significantly different $(P>0.05) . N$, number of individuals.

\begin{tabular}{|c|c|c|c|c|}
\hline \multirow[b]{3}{*}{ Host-plant race } & \multicolumn{4}{|c|}{ Weight (mg) } \\
\hline & \multicolumn{2}{|r|}{ Pupae (lab) } & \multicolumn{2}{|c|}{ Adults (field) } \\
\hline & $N$ & Mean $\pm \mathrm{SE}$ & $N$ & Mean \pm SE \\
\hline \multicolumn{5}{|l|}{ Mugwort } \\
\hline Males & 16 & $72.7 \pm 1.14^{\mathrm{a}}$ & 21 & $30.5 \pm 0.63^{\mathrm{a}}$ \\
\hline Females & 30 & $95.4 \pm 2.17^{\mathrm{b}}$ & 26 & $54.8 \pm 1.20^{\mathrm{b}}$ \\
\hline \multicolumn{5}{|l|}{ Maize } \\
\hline Males & 63 & $78.2 \pm 1.04^{\mathrm{a}}$ & 104 & $32.8 \pm 0.53^{a}$ \\
\hline Females & 83 & $109.3 \pm 1.71^{\mathrm{c}}$ & 105 & $55.2 \pm 1.05^{b}$ \\
\hline
\end{tabular}

single gland, which produced Z11-14:OAc and E11-14:OAc in a ratio of 0.6:99.4. These results strongly suggest that all 32 mugwort females were $\mathrm{E}$ females. The combined frequency of $\mathrm{Z}$ and hybrid females within this population of the mugwort race was less than $9 \%$, using a threshold level of $5 \%$.

\section{Overwintering Mortality, Parasitism, and Moth Weight}

Overwintering mortality and parasitism.-In laboratory conditions, only 46 (about 25\%) of the 198 mugwort larvae extracted from set 2 stalks reached the adult stage. The overwintering mortality was much lower (Fisher's exact test, $P$ $<0.0001)$ in the maize race, for which we obtained 138 (about $75 \%$ ) adults from the 183 larvae extracted from the second set of stalks. This difference in mortality was mainly due to a parasitoid, Macrocentrus cingulum Brischke-also known as Macrocentrus grandii Goidanich and Macrocentrus gifuensis Ashmead-a braconid known to parasitize not only $O$. nubilalis but also $O$. furnacalis, Sitochroa verticalis, and some members of the Noctuidae and Nymphalidae (van Achterberg 1993). In set 2, this parasitoid killed 53\% of the larvae overwintering on mugwort but none of the larvae overwintering on maize.

It was not possible to calculate mortality during the overwintering period in natural conditions accurately because the exact number of larvae that were inside the stalks was unknown. Nevertheless, the number of larvae present in the stalks can be estimated from the numbers of larvae extracted from set 1 and 2 stalks. For these two sets, we obtained ECB population densities of 0.56 and 0.55 larvae per stalk for mugwort and maize, respectively, so we can estimate that approximately 550 larvae were monitored in the cages containing the third set of stalks. As these cages yielded 47 moths from mugwort stalks and 209 moths from maize stalks, ECB mortality during the overwintering period in field conditions was approximately $90 \%$ on mugwort and approximately $60 \%$ on maize.

Weight analysis. - We weighed the pupae of the second set of stalks and the adults of the third set. We found that males were smaller than females in both races: the difference was approximately $35 \%$ for pupae and approximately $75 \%$ for adults, with $P<0.0001$ in all cases (Table 3 ). The weights of pupae and adult males did not differ significantly between the two races ( $t$-tests, $F_{1,72}=3.33, P=0.072$ for the pupae and $F_{1,122}=3.07, P=0.082$ for the adults). The female pupae from set 2 that originated from mugwort were smaller than those that originated from maize ( $t$-test, $F_{1,108}=12.20$, $P<0.0001)$. This difference cannot be due to the presence of $M$. cingulum since this parasitoid emerged exclusively from diapausing larvae and therefore are not present inside ECB pupae. This difference was not confirmed in the third

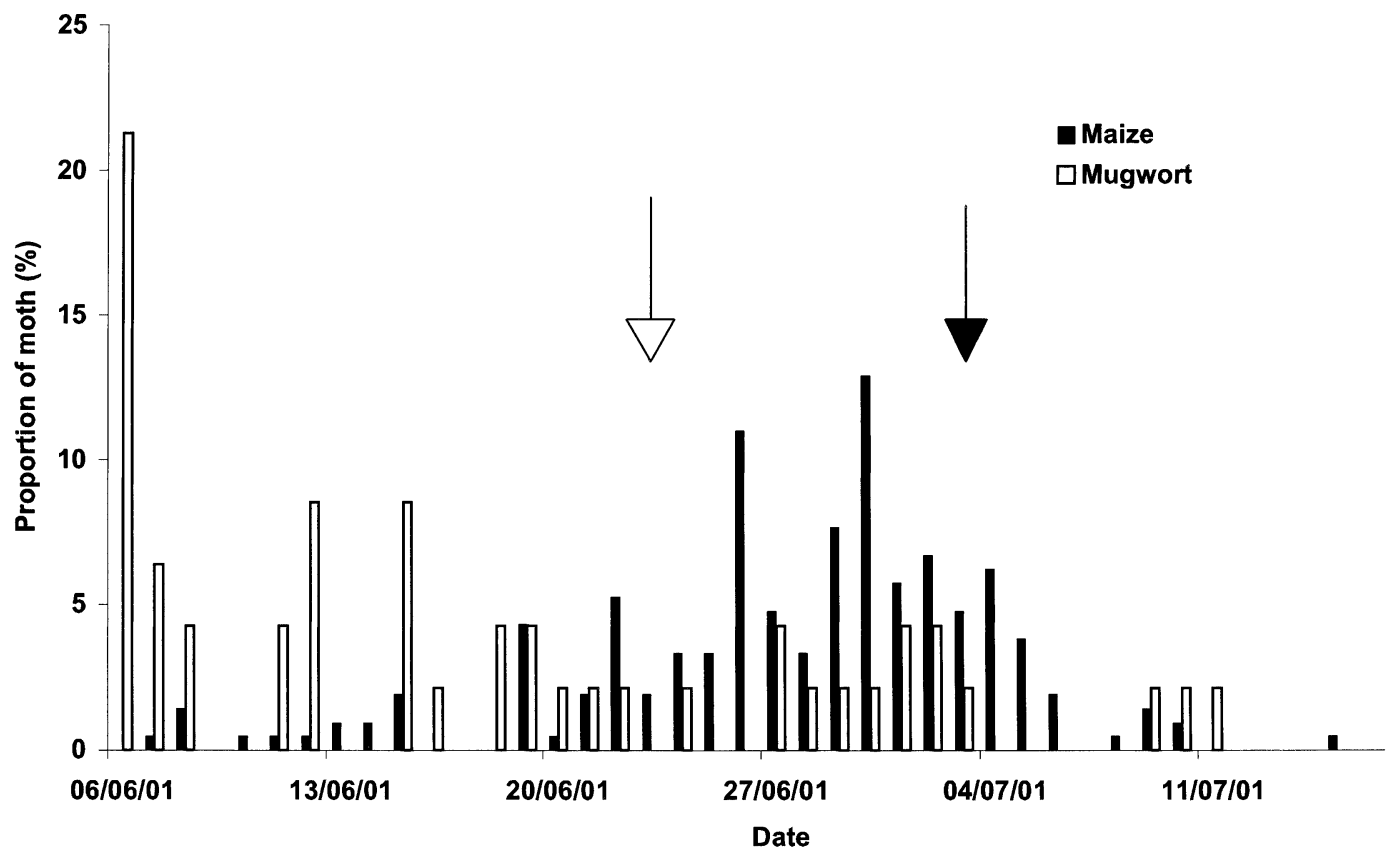

FIG. 2. Proportion of moths emerging under field conditions. Filled and open arrows indicate the mean day of pupation and emergence for the maize and mugwort races, respectively. 
TABLE 4. Estimator $\hat{f}$ of $F_{\text {IS }}$ and $P$-value for deviation from Hardy-Weinberg equilibrium at each locus and across all loci.

\begin{tabular}{|c|c|c|c|c|c|c|c|c|c|c|c|c|}
\hline \multirow[b]{3}{*}{ Locus } & \multicolumn{6}{|c|}{ Mugwort race } & \multicolumn{6}{|c|}{ Maize race } \\
\hline & \multicolumn{2}{|c|}{$\begin{array}{c}\text { Larvae } \\
N^{\mathrm{a}}=81(42)\end{array}$} & \multicolumn{2}{|c|}{$\begin{array}{l}\text { Adults (field) } \\
N^{\mathrm{a}}=47 \text { (21) }\end{array}$} & \multicolumn{2}{|c|}{$\begin{array}{c}\text { Adults (lab) } \\
N^{\mathrm{a}}=46(16)\end{array}$} & \multicolumn{2}{|c|}{$\begin{array}{c}\text { Larvae } \\
N^{\mathrm{a}}=90(37)\end{array}$} & \multicolumn{2}{|c|}{$\begin{array}{c}\text { Adults (field) } \\
N^{\mathrm{a}}=209(104)\end{array}$} & \multicolumn{2}{|c|}{$\begin{array}{c}\text { Adults (lab) } \\
N^{\mathrm{a}}=138(58)\end{array}$} \\
\hline & $\hat{f}$ & $P$ & $\hat{f}$ & $P$ & $\hat{f}$ & $P$ & $\hat{f}$ & $P$ & $\hat{f}$ & $P$ & $\hat{f}$ & $P$ \\
\hline$T p i^{\mathrm{b}}$ & 0.248 & 0.035 & 0.079 & 0.663 & 0.449 & 0.040 & -0.132 & 0.649 & 0.012 & 1.00 & -0.027 & 1.00 \\
\hline Gpi & 0.127 & 0.391 & 0.109 & 0.311 & -0.173 & 0.265 & -0.078 & 0.379 & -0.049 & 0.365 & -0.004 & 0.621 \\
\hline Aat & 0.170 & 0.078 & 0.013 & 0.767 & -0.099 & 1.00 & -0.001 & 0.194 & 0.021 & 0.111 & 0.019 & 0.342 \\
\hline$M p i$ & -0.021 & 1.00 & 0.484 & $<10^{-3}$ & 0.009 & 0.393 & 0.179 & 0.260 & 0.153 & 0.115 & 0.103 & 0.294 \\
\hline
\end{tabular}

${ }^{\text {a }} \mathrm{N}$, number of individuals (number of males).

${ }^{\mathrm{b}}$ Calculations performed for males only.

set: in natural conditions, the females of the mugwort and maize races did not differ in weight $\left(t\right.$-test, $F_{1,130}=0.026$, $P=0.872$ ).

\section{Selective Effects on Allozymes}

Deviation from Hardy-Weinberg equilibrium.-For all three sets of stalks for the maize race, we found no deviation from Hardy-Weinberg expectations at any individual locus or across all loci (Table 4). Conversely, several deviations from Hardy-Weinberg equilibrium were found within the mugwort race (Table 4). The Tpi locus showed a significant deficit of heterozygotes in overwintering larvae $(\hat{f}=0.248, P=0.035)$ and in moths emerging in laboratory conditions $(\hat{f}=0.449$, $P=0.040)$, but not in moths emerging in natural conditions $(\hat{f}=0.079, P=0.663)$. Moths emerging in natural conditions displayed a major deficit of heterozygotes at both the Mpi $(\hat{f}$ $=0.484, P<0.001)$ and the $\operatorname{Pgm}(\hat{f}=0.414, P<0.001)$ loci, responsible for the significant deficit in heterozygotes detected across all loci $(\hat{f}=0.215, P<0.001$; Table 4$)$.

Changes in allelic frequencies between overwintering larvae and adults. - The insects obtained from the three sets of maize stalks displayed very similar allelic distributions at each locus and across all loci (Table 5). A different situation was observed for the mugwort race (Table 5). Across all loci, allelic distribution differed between overwintering larvae and adults that emerged under field conditions $(P=0.002)$, the two sets differing mainly at the $M p i$ locus $(P=0.001)$. The allelic distribution at the $M p i$ locus also differed significantly
$(P=0.013)$ between the two sets of adults. This was mainly due to the higher frequency of the Mpi 60 allele and the lower frequency of the Mpi 80 allele in set 3 than in the other two sets (Fig. 3A). Finally, although not significantly different across all loci $(P=0.057)$, the overwintering larvae and the adults emerging in the laboratory displayed different allelic distributions at the Tpi locus $(P=0.012)$. This was due to the higher frequency of the Tpi 130 allele in the ECB of the second set than in the ECB of the first set (Fig. 3B).

Variations in allelic frequencies during moth emergence. Due to the limited number of individuals, we did not compare allelic frequencies between dates. Instead, for both set 2 and set 3 we pooled the moths into two time periods: the first period included individuals that emerged before the median emergence date and the second period, those emerging after this median. Within the maize race, the distribution of allelic frequencies in the insects of set 2 and 3 did not differ between the two periods (Table 6). Within the mugwort race, allelic frequencies differed between the two periods of the second set at the Tpi locus only $(P=0.008)$, this difference being close to the threshold of significance across all loci $(P=$ 0.058) (Table 6). This difference resulted from the higher frequency of the Tpi 130 allele in the first period (48\%) than in the second period (13\%; Fig. 4A). Although the same pattern-a lower frequency of the Tpi 130 allele in the second period than in the first period-was observed in the ECB of the third set (Fig. 4B), allelic frequencies at the Tpi locus did not differ significantly between the two periods $(P=$ 0.173 ; Table 6).

TABLE 5. Probability value for the exact test of allelic differentiation between overwintering larvae, adults emerging in laboratory conditions, and adults emerging in field conditions.

\begin{tabular}{|c|c|c|c|c|c|c|}
\hline \multirow[b]{2}{*}{ Host-plant race } & \multicolumn{5}{|c|}{ Locus } & \multirow[b]{2}{*}{ All } \\
\hline & $T p i$ & Gpi & Aat & $M p i$ & Pgm & \\
\hline \multicolumn{7}{|l|}{ Mugwort } \\
\hline Larvae versus adults (field) & 0.599 & 0.854 & 0.051 & 0.001 & 0.041 & 0.002 \\
\hline Adults (field) versus adults (lab) & 0.088 & 0.300 & 0.327 & 0.013 & 0.241 & 0.021 \\
\hline \multicolumn{7}{|l|}{ Maize } \\
\hline Adults (field) versus adults (lab) & 0.376 & 0.777 & 0.457 & 0.432 & 0.584 & 0.746 \\
\hline
\end{tabular}


A

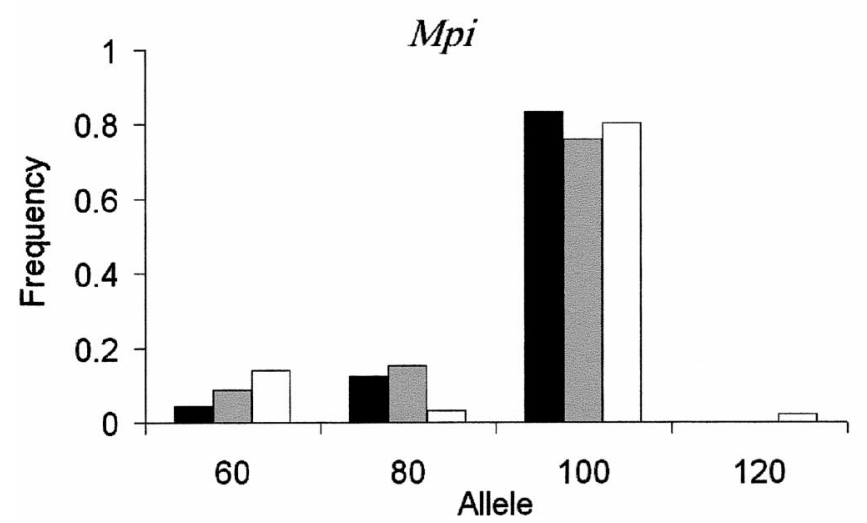

B

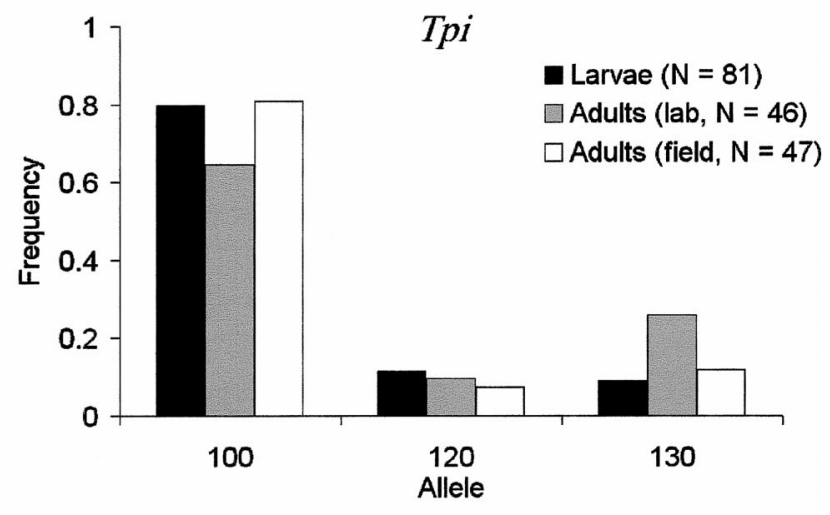

FIg. 3. Mugwort-race allele frequencies at the $M p i$ (A) and Tpi (B) loci in overwintering larvae, moths emerging in laboratory conditions and moths emerging in field conditions.

\section{Discussion}

\section{Sex Pheromone Composition}

Although $\mathrm{E}$ and $\mathrm{Z}$ populations had been previously characterized in America, they have never been linked to divergence in host-plant use. In North America (e.g., Glover et al. 1990) and Switzerland (Peña et al. 1988) both E and Z populations feed on maize. At our site, located in northern France, the situation is clearly different: the maize-race females produced mainly, if not exclusively, the $\mathrm{Z}$ blend, whereas females of the mugwort race seem to produce the $\mathrm{E}$ blend preferentially. Plant chemistry can directly affect the biosynthesis and release of sex pheromones in phytophagous insects (Landolt and Phillips 1997). However, as in other moths (Roelofs and Cardé 1977; Löfstedt 1993), the female pheromone and male response in ECB are genetically driven and independent of the host plant on which larvae are fed (Roelofs et al. 1985; Glover et al. 1990).

A similar situation occurs in the larch budmoth, Zeiraphera diniana. In this species, two sympatric host races have been reported, one feeding on larch (Larix decidua), the other feeding on cembran pine (Pinus cembra; Emelianov et al. 1995). The females of each race produce a blend of E11-14:OAc and E9-dodecenyl acetate (E9-12:OAc), but in inverse ratios. Larch-race females produce virtually $100 \%$ E11-14:OAc with traces of E9-12:OAc, whereas pine-race females produce a 1:1000 ratio of E11-14:OAc to E9-12:OAc. Males respond maximally to the pheromone blend of their own race (Priesner and Baltensweiler 1987).

The geographical distribution of the $\mathrm{E}$ and $\mathrm{Z}$ populations of European corn borer has been intensively studied in recent decades. Z populations exist throughout Canada, the U.S. Corn Belt and most parts of the world (reviewed in Hudon et al. 1989). Conversely, E populations are less common. In North America, E populations of ECB exist mainly in New York, Pennsylvania, New Jersey, North Carolina, and Massachusetts (reviewed in Hudon et al. 1989). In Europe, males responding to the $\mathrm{E}$ blend are predominantly trapped in the southern parts of Switzerland and northern parts of Italy; E males are rare or absent elsewhere (Anglade et al. 1984). Our results suggest that $\mathrm{E}$ populations also occur in populations living in northern France and feeding on mugwort but not on maize.

In laboratory conditions, $\mathrm{Z}$ males do not respond to the $\mathrm{E}$ blend and very few $\mathrm{E}$ males respond to the $\mathrm{Z}$ blend (Glover et al. 1990). Mating choice tests under confined conditions with the $\mathrm{E}$ and $\mathrm{Z}$ strains revealed that the frequency of successful interstrain crosses is much lower than that of intrastrain crosses (Liebherr and Roelofs 1975). Finally, assortative mating between the two races may be further enhanced because of the differences in calling periodicity between the E and Z ECB. Indeed, Liebherr and Roelofs (1975) found that $\mathrm{Z}$ moths begin calling, responding, and mating within one hour of darkness. In contrast, E moths do not initiate sexual behavior until about five hours after the onset of darkness.

Despite this potential for assortative mating, hybridization of $\mathrm{Z}$ and $\mathrm{E}$ moths still occurs in natural conditions. At field sites at which $\mathrm{Z}$ and $\mathrm{E}$ populations coexist on maize, some males have been attracted by hybrid blends (Klun et al. 1975; Anglade et al. 1984) and field-collected females producing hybrid blends have been described (Klun and Huettel 1988; Peña et al. 1988; Glover et al. 1990). Although the frequency of these hybrid moths is generally lower than expected under Hardy-Weinberg equilibrium (Klun and Huettel 1988) they were systematically detected in all of the locations where E and $\mathrm{Z}$ populations coexist.

Conversely, at our sampling site, the 57 females for which the pheromone blend was identified produced either the $\mathrm{E}$ (on mugwort) or $\mathrm{Z}$ (on maize) blend. The absence of hybrids is probably not the consequence of post-zygotic isolation as $\mathrm{E} / \mathrm{Z}$ hybrids seem to be equally as fit as $\mathrm{E}$ and $\mathrm{Z}$ individuals (Y. Thomas and D. Bourguet, unpubl. data). Hence, the assortative mating between $\mathrm{E}$ and $\mathrm{Z}$ moths observed in maize fields by Klun and Huettel (1988) and Glover et al. (1990) may be further enhanced at our site where $\mathrm{E}$ and $\mathrm{Z}$ moths 
TABLE 6. Probability value for the exact test of allelic differentiation between adults emerging in the first time period and those emerging in the second time period, in field and laboratory conditions.

\begin{tabular}{lcccccc}
\hline \hline & \multicolumn{5}{c}{ Locus } & \\
\cline { 2 - 6 } Host-plant race & $T p i$ & $G p i$ & Aat & Mpi & Pgm & All \\
\hline Maize & & & & & & \\
$\quad$ Lab & 0.851 & 0.786 & 0.278 & 0.500 & 0.106 & 0.509 \\
$\quad$ Field & 0.229 & 0.060 & 0.286 & 0.546 & 0.585 & 0.204 \\
Mugwort & & & & & & \\
$\quad$ Lab & 0.008 & 0.255 & 0.169 & 0.722 & 0.580 & 0.058 \\
$\quad$ Field & 0.173 & 0.723 & 0.104 & 0.118 & 0.267 & 0.112 \\
\hline
\end{tabular}

emerged from mugwort and maize, respectively. The asynchrony of the moths emerging from the two host plants (see below) may be one of the factors enhancing the decrease of $\mathrm{E} / \mathrm{Z}$ hybridization. Behavioral studies concerning male responses to the different pheromone blends are currently underway to determine the level of reproductive isolation due specifically to the mating communication system.

\section{Voltinism}

Differences in voltinism may place obvious restrictions on gene flow. Aspects of diapause completion are intimately related to voltinism, and post-diapause development (PDD) time can be used to distinguish between genetically univoltine and bivoltine field-collected larvae (Glover et al. 1990). The mean PDD time for univoltine ECB under diapausebreaking conditions $\left(30^{\circ} \mathrm{C}, 16: 8 \mathrm{~L}: \mathrm{D}\right)$ is about 44 days, whereas that for bivoltine ECB under the same conditions is approximately 15 days (Glover et al. 1992). The mean PDD times for the maize and mugwort races of ECB under our diapause-breaking conditions $\left(25^{\circ} \mathrm{C}, 16: 8 \mathrm{~L}: \mathrm{D}\right)$ were about 21 and 18 days, respectively. Thus, based on PDD time, the populations of both races were genetically bivoltine. However, the mugwort race may contain a fraction of univoltine individuals. Indeed, one male collected on mugwort displayed a PDD time of 49 days, whereas all the other moths had a PDD $\leq 34$ days (see Fig. 1A). This male was probably genetically univoltine. By combining these results with those obtained on sex pheromones, we concluded that the population collected on maize was bivoltine $\mathrm{Z}$ (bivoltine using $\mathrm{Z}$ pheromone), whereas the population sampled on mugwort was mainly, although not exclusively, bivoltine E (bivoltine using E pheromone). Therefore, at our site, voltinism does not seem to be a major component of reproductive isolation.

\section{Moth Emergence Patterns}

Host plants may differ in phenology and insects must emerge at the right time to complete their life cycle (Tauber et al. 1986). Hence, the colonization of host plants with different phenologies may select for concomitant changes in insect emergence. These changes have the potential to generate reproductive isolation among populations using different hosts. As mugwort stands appear before the sowing of maize fields (M.-T. Bethenod and D. Bourguet, pers. obs.), we expected to observe a difference in emergence pattern between the two host-plant races.
A

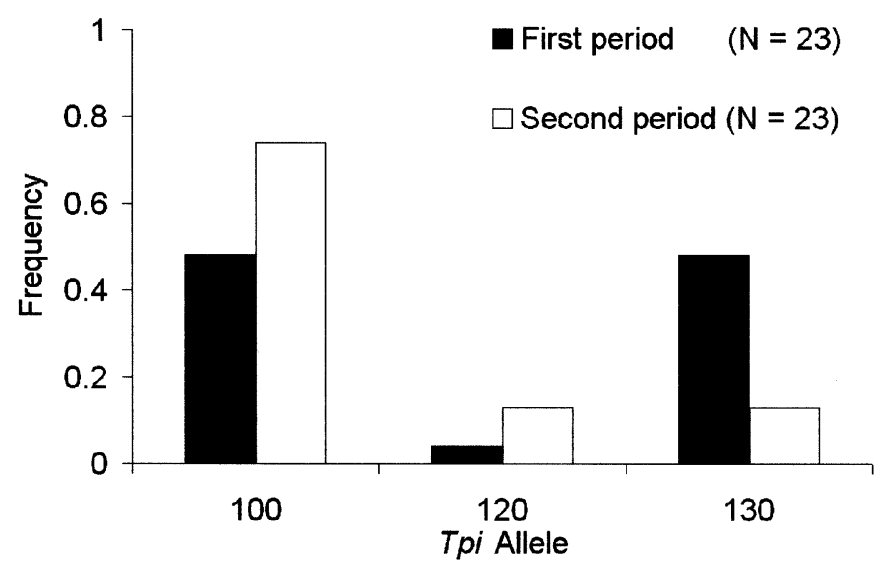

$\mathbf{B}$

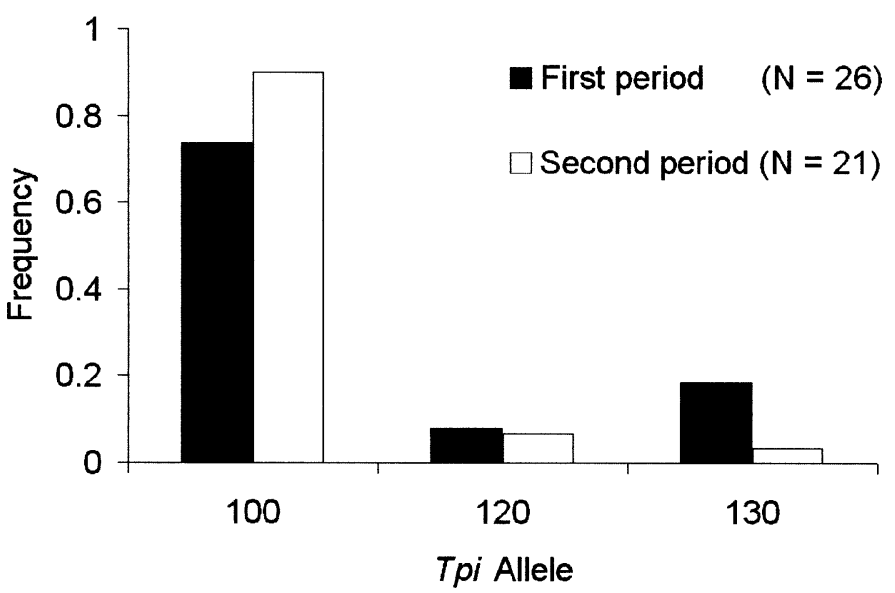

FIG. 4. Mugwort-race allele frequencies at the Tpi locus in earlier (first period) and later (second period) emerging moths under laboratory (A) and field (B) conditions.

At our study site, moths emerged earlier from mugwort than from maize. This difference was less prominent in laboratory conditions where larvae were exposed to identical temperature and humidity conditions. This indicates that the asynchrony in moth emerging timing is partly due to variations in environmental cues (e.g., chemical compounds, light, temperature, and/or humidity) induced by host plants. However, the emergence timing of the two host races remained significantly different in laboratory conditions. This was probably due to genetic differences between the two races although we cannot rule out maternal- or host-induced effects prior to the collection of the diapausing larvae.

Differences in emergence pattern between sympatric races have been described in other phytophagous insects such as the fall armyworm, Spodoptera frugiperda (Pashley et al. 1992); the yucca moth, Prodexus quiquepunctellus (Groman and Pellmyr 2000); the goldenrod ball-gall fly, Eurosta solidaginis (Craig et al. 1993); the treehopper, Enchenopa binotata (Wood et al. 1990); and the apple maggot fly, Rhagoletis 
pomonella (Feder et al. 1993; Feder 1995). In Rhagoletis pomonella, adults of the apple-feeding race emerge a mean of about ten days earlier than do the adults of the hawthornfeeding race. Although flies may live for up to four weeks, this allochronic isolation is a major component in the reproductive isolation between the two host-races (Feder and Filchak 1999). At our site, the mean difference in emergence time was also about ten days. This difference may strongly reduce interbreeding between the two races, because the lifetime of adults does not exceed 20 days (Balachowsky 1935; Fadamiro and Baker 1999).

In both races, males emerged four days earlier than females. Consequently, mugwort-race males emerged a mean of 14 days before maize-race females, whereas the difference in mean emergence time between maize-race males and mugwort-race females was only six days. This makes the potential for interbreeding asymmetric: mating between maize-race males and mugwort-race females is more likely to occur than the opposite mating. Interestingly, $\mathrm{Z}$ males are not attracted by $\mathrm{E}$ females, whereas $\mathrm{Z}$ females do attract $\mathrm{E}$ males (Glover et al. 1990). As the hybrid mating most likely to occur in nature is disfavored for reasons of sex pheromone attractiveness, this further enhances the reproductive isolation between the two races.

\section{Macrocentrus cingulum: a Factor Promoting Maize Colonization}

Parasitoid success in attacking herbivores may be influenced both directly and indirectly by the host plant of the herbivore (Price et al. 1980). Hence, a new host plant may constitute an enemy-free space for colonization, on which the phytophagous insect is likely to carry a lower parasite load (Jaenike 1990). This has already been observed in the sympatric host race of $R$. pomonella: levels of braconid parasitoid attack are much higher in fly larvae infesting the ancestral host, hawthorn, than in larvae infesting the derived host, apple (Feder 1995). Data from other tephritid species (Feder 1995) suggest that escape from parasitoids may be a common theme in host-range expansion and race formation in these flies. Hence, one factor that may contribute to the colonization of maize by the ECB is a difference in the parasite load between the two host-plants.

The parasitism of ECB larvae was studied throughout Europe between 1919 and 1926 in a remarkable survey performed by Thompson and Parker (1928). Among the parasites recovered by these authors, the braconid wasp parasitoid, $M$. cingulum, was found in up to $30 \%$ of the larvae collected on mugwort but never in those collected on maize. This parasitoid was only recovered in northern areas, including the Paris region, the location of our study site (Baker et al. 1949). Our data indicated that $M$. cingulum attacks were restricted to larvae overwintering on mugwort: wasps killed more than $50 \%$ of these larvae but none of the larvae diapausing on maize. We cannot exclude the possibility that some maize larvae were actually parasitized by $M$. cingulum but, for unknown reasons, the wasps died before emergence.

Macrocentrus cingulum is present not only in France, but also in Korea and Japan. However, in these Asian countries, this wasp has been found in ECB larvae collected on maize
(Baker et al. 1949). From 1920 to 1949, M. cingulum collected in Europe and Asia was introduced into the United States for the biological control of ECB. Interestingly, only wasps of Asian origin were found to parasitize ECB larvae feeding on maize (Baker et al. 1949), reinforcing the idea that $M$. cingulum populations in northern France cannot parasitize ECB feeding on maize.

The introduction by humans of maize into Europe (about 500 years ago) resulted in an enemy-free space for the development of phytophagous insects. By colonizing this new host, ECB populations probably escaped from numerous predators, competitors, and parasitoids, such as M. cingulum. This decrease in host-associated selection may have favored the colonization of this new host. The biotic and abiotic parameters protecting maize-race larvae from $M$. cingulum parasitism, which may include emergence time, seasonal distribution, physical protection by the maize stalk, and female wasp oviposition preference, remain to be determined.

\section{Tpi and Mpi: Two Loci under Selection}

The Tpi locus contributes significantly to genetic differentiation between the two host-plant races. One reason for this is that the Tpi 130 allele is restricted to the mugwort race. In New York State, where BE, BZ and UZ (univoltine using $\mathrm{Z}$ pheromone) populations coexist in sympatry (Roelofs et al. 1985), the Tpi locus also displayed the greatest genetic variations. In these populations, Glover et al. (1991) found only two Tpi alleles: Tpi-1 and Tpi-2. BE populations were all fixed for the Tpi-1 loci, whereas in UZ and BZ populations, the frequency of the Tpi-1 allele ranged from 0.17 to 0.52 . Thus, BE and BZ were strongly differentiated at this locus and the Tpi-2 allele was restricted to $\mathrm{Z}$ populations. However, the relationship between the Tpi 100, Tpi 120, and Tpi 130 alleles (the three Tpi alleles detected at our site) and the Tpi1 and Tpi-2 alleles detected in New York State, if indeed there is such a relationship, remains unclear.

Genetic composition at the Tpi locus also seems to be subject to selection in the mugwort race. In males, this locus shows a significant heterozygote deficit in overwintering larvae as previously found in most populations collected on mugwort (Bourguet et al. 2000; Martel et al. 2003). Moreover the Tpi 130 allele was significantly more frequent in adults emerging in laboratory conditions than in overwintering larvae. One possible explanation for this is that larvae diapausing on mugwort were a mixture of two populations (e.g., $\mathrm{UE}$ - univoltine using E pheromone - and BE, or BE and BZ) that are genetically differentiated at the Tpi locus, each at Hardy-Weinberg equilibrium. If this is the case, the heterozygote deficit would be a Wahlund effect and the increase in the frequency of the Tpi 130 allele in adults would be the consequence of the differential mortality of individuals from these two populations during the overwintering period. However, this explanation is unlikely for two reasons. First, the heterozygote deficit found in diapausing larvae remained significant in adults emerging in laboratory conditions despite the significant variations of allelic frequencies at the Tpi locus. Second, in adults emerging in natural conditions the allelic frequencies at the Tpi locus were not significantly different from those found in diapausing larvae; and geno- 
typic frequencies did not differ from Hardy-Weinberg expectations.

Selection at the Tpi locus in the mugwort race is further suggested by the variations in allele frequency during moth emergence. Indeed, the Tpi 130 allele is present at a higher proportion in the earlier emerging moths than in those that emerged later. This pattern of emergence fits the pattern of interrace difference: the maize race, which does not display the Tpi 130 allele, emerged later in both natural and laboratory conditions. This strengthens the idea that the difference in moth emergence timing between the two races is partly due to differences in genetic background.

The occurrence of selection at the Tpi locus or at linked loci was expected. In ECB, this locus is located on the $\mathrm{Z}$ sex chromosome and is tightly linked to the genes involved in the sex pheromone behavioral responses of males (Glover et al. 1990) and those controlling PDD time (Glover et al. 1992). Genetic differences in day length sensitivity - a major component in diapause induction-and growth rate between $B$ and U strains are also sex-linked (Stengel and Schubert 1982). In $R$. pomonella, variations in developmental timing involve six allozyme loci in three regions of the genome (Feder et al. 1997; Filchak et al. 1999). At these loci, some alleles are correlated with the rapid development of larvae, premature diapause termination, and the early emergence of the flies within each host-plant race. In ECB, the relationships between the Tpi alleles, developmental timing, and host-plantrelated fitness require further study.

The autosomal region of the genome containing the $\mathrm{Mpi}$ locus is also subject to selection. In overwintering larvae, this locus showed a much higher level of differentiation than did the other four loci investigated in this study. This higher level of differentiation also occurred at other sites (Bourguet et al. 2000) and throughout the entire geographical range of ECB on mugwort in France (Martel et al. 2003). The second interesting feature at the $\mathrm{Mpi}$ locus is marked differentiation between overwintering larvae and adults emerging in the field. The overwintering mortality induced an increase in the frequency of the Mpi 60 allele and a decrease in the frequency of the Mpi 80 allele. This change in genotypic composition is not due to $M$. cingulum, because the allelic composition of $M p i$ did not differ between overwintering larvae and the mugwort-race moths emerging in laboratory conditions. Despite changes in allelic frequencies in larvae and adults, the allelic composition of the Mpi locus may remain the same over many years and large areas of space (Martel et al. 2003; D. Bourguet, M.-T. Bethenod, and Y. Thomas, unpubl. data). This may be due to unknown balancing selection at this locus.

\section{Conclusion}

Two host-plants races of the European corn borer have recently been identified in northern France (Bourguet et al. 2000; Martel et al. 2003). Although the level of genetic differentiation between populations feeding on the two host plants is low, the genetic isolation by geographic distance patterns of the two races suggests a very low level of gene flow between races (Martel et al. 2003). We show here that two factors may reduce the likelihood of hybridization between sympatric populations of the two host-plant races. At our sampling site, individuals feeding on the two host plants used different mating recognition systems and did not emerge synchronously. The combination of these two factors provides a source of strong assortative mating, as suggesting by the absence of females producing hybrid pheromone blends in the two races.

These results cannot be generalized to other geographical areas. Although ECB is widely distributed in Europe, it only colonizes mugwort in the northern part of Europe (Thompson and Parker 1928; Martel et al. 2003). In Switzerland, where mugwort is not infested, E and $\mathrm{Z}$ populations have been collected on maize (Peña et al. 1988). Similarly, both pheromonal populations have been sampled in U.S. maize fields (e.g., Roelofs et al. 1985; Glover et al. 1990). Hence, further studies must be performed at other sites and in other geographical locations to unravel the relationships between pheromones, developmental timing, and host-plant colonization.

If the difference in emergence timing is driven by phenological differences between host species, then assortative mating between mugwort and maize races emerged as a byproduct of ecological specialization. Conversely, the genetic differentiation of the mating communication system may have been selected to reinforce the prezygotic isolation in a later stage of divergence. A recent evolution of this trait is congruent with the lack of genetic differentiation at the mitochondrial DNA and pheromone-binding protein between $\mathrm{E}$ and Z populations (Marçon et al. 1999; Willett and Harrison 1999; Martel et al. 2003). The indirect selection of assortative mating and its reinforcement could have been promoted by the sex linkage of genes involved in male pheromone response and those involved in developmental timing. The association between traits that distinguish closely related taxa and the sexual $\mathrm{Z}$ chromosome is a usual feature in Lepidoptera (Sperling 1994; Pashley 1998). This Z-linked bias in combination with female heterogamety could enhance the rate of assortative mating by shortening the time required for the evolution of premating barriers to reproduction (Pashley 1998). Additional premating barriers to gene flow between maize and mugwort races, such as host-plant recognition and the fidelity of the female to her host, and the genome location of these barriers remain to be studied.

Finally, this study provides the first insight into differences in fitness between the two host-plant races. We found that the parasitoid wasp, Macrocentrus cingulum, strongly reduces the proportion of mugwort-race larvae that emerge as adults. Hence, by colonizing maize, ECB populations probably escaped from numerous predators, competitors, and parasitoids. However, this gain of fitness is counterbalanced by human crop management (larvae being killed during the harvesting process, use of chemical pesticides and parasitoids) and possibly also by a lower feeding performance on maize. An investigation of feeding adaptation is therefore the next logical step for testing the presence of fitness trade-offs between the two $O$. nubilalis host-race environments.

\section{ACKNOWLEDGMENTS}

We thank C. Buisson for help in sampling and F. Rousset and two anonymous reviewers for helpful comments. This work was supported by the Ministère de l'Education Na- 
tionale de la Recherche et de la Technologie, Action Organisée, Impact des Organismes Génétiquement Modifiés.

\section{Literature Cited}

Abrahamson, W. G., M. D. Eubanks, C. P. Blair, and A. V. Whipple. 2001. Gall flies, inquilines, and goldenrods: a model for hostrace formation and sympatric speciation. Am. Zool. 41:928-938.

Anglade, P., J. Stockel, and many others. 1984. Intraspecific sexpheromone variability in the European corn borer, Ostrinia nubilalis Hbn. (Lepidoptera, Pyralidae). Agronomie 4:183-187.

Baker, W. A., W. G. Bradley, and C. A. Clark. 1949. Biological control of the European corn borer in the United States. U.S. Dep. Agric. Tech. Bull. 983:1-185.

Balachowsky, M. 1935. Les insectes nuisibles aux céréales et aux graminées. Les insectes nuisibles aux plantes cultivées. Etablissements Busson, Paris.

Berlocher, S. H., and J. L. Feder. 2002. Sympatric speciation in phytophagous insects: moving beyond controversy? Annu. Rev. Entomol. 47:773-815.

Bourguet, D., M.-T. Bethenod, C. Trouvé, and F. Viard. 2000. Host plant diversity of the European corn borer Ostrinia nubilalis: what chance for sustainable transgenic insecticidal $B t$ maize? Proc. R. Soc. Lond. B 267:1177-1184.

Bush, G. L. 1975. Modes of animal speciation. Annu. Rev. Syst. 6:339-364.

Cardé, R. T., W. L. Roelofs, R. G. Harrison, A. T. Vawter, P. F. Brussard, A. Mutuura, and E. Munroe. 1978. European corn borer: pheromone polymorphism or sibling species? Science 199:555-556.

Carroll, S. P., H. Dingle, T. R. Famula, and C. W. Fox. 2001. Genetic architecture of adaptive differentiation in evolving host races of the soapberry bug, Jadera haematoloma. Genetica 112 113:257-272.

Craig, T. P., J. K. Itami, W. G. Abrahamson, and J. D. Horner. 1993. Behavioral evidence for host-race formation in Eurosta solidiganis. Evolution 47:1696-1710.

Craig, T. P., J. D. Horner, and J. K. Itami. 2001. Genetics, experience, and host-plant preference in Eurosta solidaginis: implications for host shifts and speciation. Evolution 55:773-782.

Dieckmann, U., and M. Doebeli. 1999. On the origin of species by sympatric speciation. Nature 400:354-357.

Emelianov, I., J. Mallet, and W. Baltensweiler. 1995. Genetic differentiation in Zeiraphera diniana (Lepidoptera, Tortricidae, the larch budmoth): polymorphism, host races or sibling species. Heredity 75:416-424.

Emelianov, I., M. Drès, W. Baltensweiler, and J. Mallet. 2001. Hostinduced assortative mating in host races of the larch budmoth. Evolution 55:2002-2010.

Fadamiro, H. Y., and T. C. Baker. 1999. Reproductive performance and longevity of female European corn borer, Ostrinia nubilalis: effects of multiple mating, delays in mating, and adult feeding. J. Insect Physiol. 45:385-392.

Feder, J. L. 1995. The effects of parasitoids on sympatric host races of Rhagoletis pomonella (Diptera: Tephritidae). Ecology 76: 801-813.

Feder, J. L., and K. E. Filchak. 1999. It's about time: the evidence for host plant-mediated selection in the apple maggot fly, Rhagoletis pomonella, and its implications for fitness trade-offs in phytophagous insects. Entomol. Exp. Appl. 91:211-225.

Feder, J. L., T. A. Hunt, and L. Bush. 1993. The effects of climate, host plant phenology and host fidelity on the genetics of apple and hawthorn infesting races of Rhagoletis pomonella. Entomol. Exp. Appl. 69:117-135.

Feder, J. L., S. B. Opp, B. Wlazlo, K. Reynolds, W. Go, and S. Spisak. 1994. Host fidelity is an effective premating barrier between sympatric races of the apple maggot fly. Proc. Natl. Acad. Sci. USA 91:7990-7994.

Feder, J. L., J. B. Roethele, B. Wlazlo, and S. H. Berlocher. 1997. Selective maintenance of allozyme differences among sympatric host races of the apple maggot fly. Proc. Natl. Acad. Sci. USA 94:11417-11421
Feder, J. L., S. H. Berlocher, and S. B. Opp. 1998. Sympatric hostrace formation and speciation in Rhagoletis (Diptera: Tephritidae): a tale of two species for Charles D. Pp. 408-441 in S. Mopper and S. Strauss, eds. Genetic structure and local adaptation in natural insect populations. Chapman and Hall, New York.

Felsenstein, J. 1981. Scepticism towards Santa Rosalia, or why are there so few kinds of animals? Evolution 35:124-138.

Filchak, K. E., J. L. Feder, J. B. Roethele, and U. Stolz. 1999. A field test for host-plant dependent selection on larvae of the apple maggot fly, Rhagoletis pomonella. Evolution 53:187-200.

Frérot, B., C. Malosse, and A.-H. Cain. 1997. Solid-phase microextraction (SPME): A new tool in pheromone identification in Lepidoptera. J. High Resolut. Chromatogr. 20:340-342.

Glover, T. J., M. Campbell, P. S. Robbins, and W. L. Roelofs. 1990. Sex-linked control of sex pheromone behavioral responses in European corn borer moths (Ostrinia nubilalis) confirmed with TPI marker gene. Arch. Insect Biochem. Physiol. 15:67-77.

Glover, T. J., J. J. Knodel, P. S. Robbins, C. J. Eckenrode, and W. L. Roelofs. 1991. Gene flow among three races of European corn borer (Lepidoptera: Pyralidae) in New York State. J. Econ. Entomol. 20:1356-1362.

Glover, T. J., P. S. Robbins, C. J. Eckenrode, and W. L. Roelofs 1992. Genetic control of voltinism characteristics in European corn borer races assessed with a marker gene. Arch. Insect Biochem. Physiol. 20:107-117.

Goudet, J. 1995. FSTAT Version 1.2: a computer program to calculate F-statistics. J. Hered. 86:485-486.

Groman, J. D., and O. Pellmyr. 2000. Rapid evolution and specialization following host colonization in a yucca moth. J. Evol. Biol. 13:223-236.

Harrison, R. G., and A. T. Vawter. 1977. Allozyme differentiation between pheromone strains of the European corn borer, Ostrinia nubilalis. Ann. Entomol. Soc. Am. 70:717-720.

Hodgson, B. E. 1928. The host plants of the European corn borer in New England. U.S. Dep. Agric. Tech. Bull. 77:1-63.

Hudon, M., E. J. LeRoux, and D. G. Harcourt. 1989. Seventy years of European corn borer (Ostrinia nubilalis) research in North America. Agric. Zool. Rev. 3:53-96.

Jaenike, J. 1990. Host specialization in phytophagous insects. Annu. Rev. Ecol. Syst. 21:243-273.

Klun, J. A., and M. D. Huettel. 1988. Genetic regulation of sex pheromone production and response: interaction of sympatric pheromonal types of European corn borer, Ostrinia nubilalis (Lepidoptera: Pyralidae). J. Chem. Ecol. 14:2047-2061.

Klun, J. A., and S. Maini. 1979. Genetic basis of an insect chemical communication system: the European corn borer. Environ. Entomol. 8:423-426.

Klun, J. A., D. L. Chapman, K. C. Mattes, P. W. Wotjkowski, M. Beroza, and P. E. Sonnet. 1973. Insect sex pheromone: minor amount of the opposite geometrical isomer critical to attraction. Science 181:661-663.

Klun, J. A., and many others. 1975. Insect sex pheromones: intraspecific pheromonal variability of Ostrinia nubilalis in North America and Europe. Environ. Entomol. 4:891-894.

Kondrashov, A. S., and F. A. Kondrashov. 1999. Interactions among quantitative traits in the course of sympatric speciation. Nature 400:351-354.

Kochansky, J., R. T. Cardé, J. Liebherr, and W. L. Roelofs. 1975. Sex pheromone of the European corn borer Ostrinia nubilalis (Lepidoptera: Pyralidae), in New York. J. Chem. Entomol. 1: $225-231$.

Landolt, P. J., and T. W. Phillips. 1997. Host plant influences on sex pheromone behavior of phytophagous insects. Annu. Rev. Entomol. 42:371-391.

Liebherr, J., and W. L. Roelofs. 1975. Laboratory hybridization and mating period studies using two pheromone strains of Ostrinia nubilalis. Ann. Entomol. Soc. Am. 68:305-309.

Löfstedt, C. 1993. Moth pheromone genetics and evolution. Philos. Trans. R. Soc. Lond. B. 340:167-177.

Losos, J. B., K. B. Warheit, and T. W. Schoener 1997. Adaptive differentiation following experimental island colonization in Anolis lizards. Nature 387:70-73. 
Losos, J. B., T. R. Jackman, A. Larson, K. de Queiroz, and L. Rodriguez-Schettino. 1998. Contingency and determinism in replicated adaptative radiation of island lizards. Science 279: 2115-2118.

Losos, J. B., D. A. Creer, D. Glossip, R. Goellner, A. Hampton, G. Roberts, N. Haskell, P. Taylor, and J. Ettling. 2000. Evolutionary implications of phenotypic plasticity in the hindlimb of the lizard Anolis sagrei. Evolution 54:301-305.

Marçon, P. C. R. G., D. B. Taylor, C. E. Mason, R. L. Hellmich, and D. B. Siegfried. 1999. Genetic similarity among pheromone and voltinism races of Ostrinia nubilalis (Hübner) (Lepidoptera: Crambidae). Insect Mol. Biol. 8:213-221.

Martel, C., A. Réjasse, F. Rousset, M.-T. Bethenod, and D. Bourguet. 2003. Host-plant associated genetic differentiation in Northern French populations of the European corn borer. Heredity 90:141-149.

McPheron, B. A., D. C. Smith, and S. H. Berlocher. 1988. Genetic differentiation between sympatric host races of the apple maggot fly Rhagoletis pomonella. Nature 336:64-66.

Orr, M. R., and T. B. Smith. 1998. Ecology and speciation. Trends Ecol. Evol. 13:502-505.

Pashley, D. P. 1998. Sex linkage and speciation in Lepidoptera. Pp. 309-319 in D. J. Howard and S. H. Berlocher, eds. Endless forms: species and speciation. Oxford Univ. Press, New York.

Pashley, D. P., A. M. Hammond, and T. N. Hardy. 1992. Reproductive isolating mechanisms in fall armyworm host strains (Lepidoptera: Noctuidae). Ann. Entomol. Soc. Am. 85:400-405.

Pasteur, N., G. Pasteur, F. Bonhomme, J. Catalan, and J. BrittonDavidian. 1987. Manuel technique de génétique par electrophorèse des protéines. Lavoisier, Paris.

Peña, A., H. Arn, H.-R. Buser, S. Rauscher, F. Bigler, R. Bruetti, S. Maini, and M. Toth. 1988. Sex pheromone of European corn borer, Ostrinia nubilalis: polymorphism in various laboratory and field strains. J. Chem. Ecol. 14:1359-1366.

Price, P. W., C. E. Bouton, P. Gross, B. A. McPheron, J. N. Thompson, and A. E. Weis. 1980. Interactions among three trophic levels: influence of plants on interactions between insect herbivores and natural enemies. Annu. Rev. Ecol. Syst. 11:41-65.

Priesner, E., and W. Baltensweiler. 1987. A study of pheromone polymorphism in Zeiraphera diniana Gn (Lep, Tortricidae). 1. Male pheromonal response types in European wild populations, 1978-85. J. Appl. Entomol. 104:234-256.

Raymond, M., and F. Rousset. 1995. GENEPOP Version 1.2: population genetics software for exact tests and eucumenicism. J. Hered. 86:248-249.

Rice, W. R. 1984. Disruptive selection on habitat preference and the evolution of reproductive isolation: a simulation study. Evolution 38:1251-1260.

1987. Speciation via habitat specialization: the evolution of reproductive isolation as a correlated character. Evol. Ecol. $1: 301-314$

Roelofs, W. L., and R. T. Cardé. 1977. Responses of Lepidoptera to synthetic sex pheromone chemicals and their analogues. Annu. Rev. Entomol. 22:377-405.
Roelofs, W. L., J. W. Du, X.-H. Tang, P. Robbins, and C. J. Eckenrode. 1985. Three European corn borer populations in New York based on sex pheromones and voltinism. J. Chem. Ecol. 11:829-836.

Schluter, D. 1998. Ecological causes of speciation. Pp. 114-129 in D. J. Howard and S. H. Berlocher, eds. Endless forms: species and speciation. Oxford Univ. Press, New York.

2001. Ecology and the origin of species. Trends Ecol. Evol. $16: 372-380$.

Sokal, R. R., and F. J. Rohlf. 1981. Biometry. 2d ed. Freeman, New York.

Sperling, F. A. H. 1994. Sex-linked genes and species differences in Lepidoptera. Can. Entomol. 126:807-818.

Stengel, M., and G. Schubert. 1982. Etude comparative de la vitesse de croissance et de la sensibilité à la photopériode de deux races de pyrales du mais (Ostrinia nubilalis Hübn., Lepidoptera, Pyralidae) et de leurs hybrides. Agronomie 2:989-994.

Tauber, M. J., C. A. Tauber, and S. Masaki. 1986. Seasonal adaptation of insects. Oxford Univ. Press, New York.

Thompson, W. R., and H. L. Parker. 1928. The European corn borer and its controlling factors in Europe. U.S. Dep. Agric. Tech. Bull. 59:1-62.

van Achterberg, C. 1993. Revision of the subfamily Macrocentrinae Foerster (Hymenoptera: Braconidae) from the palearctic region. The Nationaal Natuurhistorisch Museum, Leiden, The Netherlands.

Via, S. 1999. Reproductive isolation between sympatric races of pea aphids. I. Gene flow restriction and habitat choice. Evolution 53:1446-1457.

. 2001. Sympatric speciation in animals: the ugly duckling grows up. Trends Ecol. Evol. 16:381-390.

Via, S., A. C. Bouck, and S. Skillman. 2000. Reproductive isolation between divergent races of pea aphids on two hosts. II. Selection against migrants and hybrids in the parental environments. Evolution 54:1626-1637.

Weir, B. S., and C. C. Cockerham. 1984. Estimating $F$-statistics for the analysis of population structure. Evolution 38:1358-1370.

Willett, C. S., and R. G. Harrison. 1999. Insights into genome differentiation: pheromone-binding protein variation and population history in the European corn borer (Ostrinia nubilalis). Genetics 153:1743-1751.

Wilson, A. B., K. Noack-Kunnmann, and A. Meyer. 2000. Incipient speciation in sympatric Nicaraguan crater lake cichlid fishes: sexual selection versus ecological diversification. Proc. R. Soc. Lond. B 267:2133-2141.

Wood, T. K., and M. Keese. 1990. Host-plant-induced assortative mating in Enchenopa treehoppers. Evolution 44:619-628.

Wood, T. K., K. L. Olmstead, and S. I. Guttman. 1990. Insect phenology mediated by host-plant water relations. Evolution 44: 629-636.

Wood, T. K., K. J. Tilmon, A. B. Shantz, and C. K. Harris. 1999. The role of host-plant fidelity in initiating insect race formation. Evol. Ecol. Res. 1:317-332.

Corresponding Editor: S. Pitnick 